This item was submitted to Loughborough's Research Repository by the author.

Items in Figshare are protected by copyright, with all rights reserved, unless otherwise indicated.

\title{
Accessible housing? One man's battle to get a foot through the door
}

PLEASE CITE THE PUBLISHED VERSION

http://www.taylorandfrancis.com/

PUBLISHER

(C) Taylor \& Francis

VERSION

AM (Accepted Manuscript)

LICENCE

CC BY-NC-ND 4.0

REPOSITORY RECORD

McDermott, Hilary, Roger Haslam, and Alistair G.F. Gibb. 2019. "Accessible Housing? One Man's Battle to Get a Foot Through the Door". figshare. https://hdl.handle.net/2134/8357. 
This item was submitted to Loughborough's Institutional Repository (https://dspace.lboro.ac.uk/) by the author and is made available under the following Creative Commons Licence conditions.

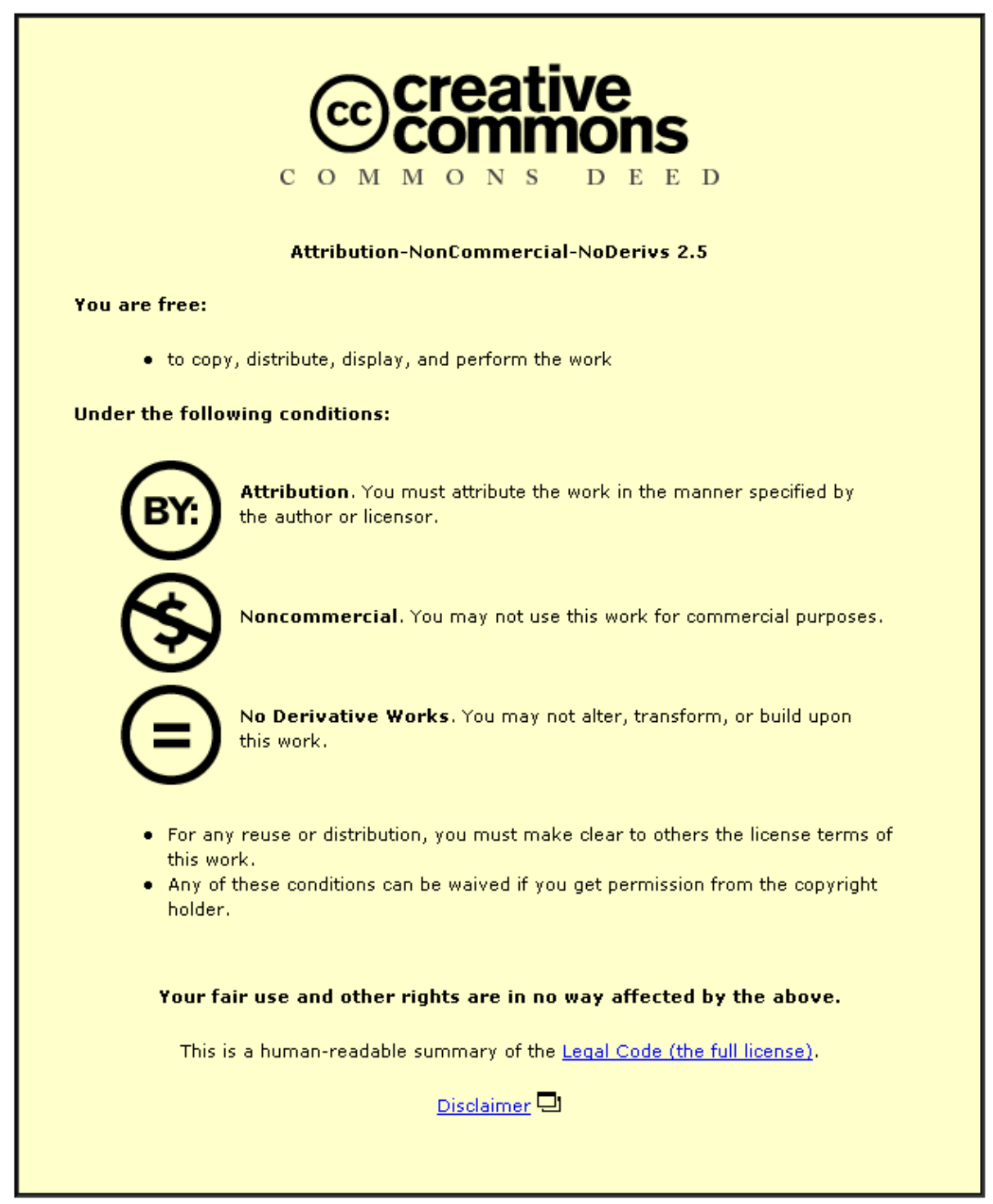

For the full text of this licence, please go to: http://creativecommons.org/licenses/by-nc-nd/2.5/ 


\title{
ACCESSIBLE HOUSING? ONE MAN'S BATTLE TO GET A FOOT THROUGH THE DOOR
}

\author{
H.J. McDermott ${ }^{1}$, R.A. Haslam ${ }^{1}$ and A.G. Gibb ${ }^{2}$ \\ ${ }^{1}$ Health \& Safety Ergonomics Unit, Department of Human Sciences, \\ Loughborough University, Loughborough, Leicestershire LE11 3TU \\ ${ }^{2}$ Department of Civil and Building Engineering, Loughborough University, \\ Loughborough, Leicestershire LE11 3TU
}

\begin{abstract}
In 2000 - 2001, 18\% of adults in England aged 16 and over reported having some form of disability, $5 \%$ of whom reported having a serious disability. The most common type of disability reported amongst adults was loco motor disability. Current legislation on housing design, to incorporate the needs of those individuals with physical disabilities, is contained within Part $\mathrm{M}$ of the Building Regulations. These requirements have had a significant impact upon dwelling design. This case study documents the experiences of a disabled man occupying a brand new home. Forming part of a wider research project, this study identifies how current Building Regulations only go some way in accommodating the needs of those with a disability and that in some 'parts' these regulations display a lack of systems thinking.
\end{abstract}

\section{Introduction}

In 2000 - 2001, 18\% of adults in England aged 16 and over reported having some form of disability, $5 \%$ of whom reported having a serious disability. The most common type of disability reported amongst adults was loco motor disability (Department of Health, 2003), the issue most affected by housing (Heywood, 2004).

Up until the 1990's, the majority of housing within Britain was not accessible to wheelchair users (Barnes, 1991), and the provision of housing for the disabled was guided by policies which were firmly rooted within an individual model of disability (Stewart et al, 1999). Such a view places the 'disability' within the individual.

The paradigm shift from the individual, or medical model of disability to the social model of disability informed British housing policy during the 1990's and reflected a growing acceptance of a collective responsibility to create a fully inclusive environment. Stewart et al, 1999, for example, argue that the inability to access a dwelling in a wheelchair is not the result of a disability, but due to the fact that architects have consistently failed to design dwellings which are accessible to everyone. Instead of viewing the needs of the disabled as 'special needs', requiring separate provisions for 


\section{In Contemporary Ergonomics 2006 (edited by Philip D. Bust) Taylor \& Francis; London}

housing, the social model of disability supports a collective response to a socially created problem.

In 1999, the scope of Part $\mathrm{M}$ of the Building Regulations relating to disabled access to public buildings, was extended to include new dwellings. These regulations have had a major impact upon dwelling design, but have been the subject of intense disapproval by builders on the grounds of impracticality and cost, and condemnation by disabled groups on the grounds that they do not go far enough (Ridout, 1997). Indeed, the overall aim of the regulations, to promote 'visitabilty' housing, has been heavily criticised. Madigan and Milner (1999) argue that such a label places emphasis on the occasional visitor rather than emphasising the more important objective - to make homes adaptable for a whole range of future occupiers.

Imrie, (2004) argues that the physical design of the dwelling and home environment can have a significant impact on the health and well-being of an individual and that the design of the majority of dwellings is underpinned by values that do not relate to disabled people. Heywood, (2004) identified a number of health outcomes that were associated with unadapted or badly adapted housing which fully support Imrie's argument. These health outcomes included pain, accidents, exacerbated physiological illness and psychological illness. Such findings have major implications in respect to Part M of the Building Regulations and the health, safety and well-being of disabled people within Britain.

An improved understanding of the ways in which disabled people interact with their home would benefit those responsible for the design and construction of new homes, and would also inform those responsible for the development of building codes and Regulations.

\section{Methods}

This case study documents the experiences of a disabled man, recently having occupied a new build home. The case study is taken from a wider research project which explored the interaction between design, usability and occupier behaviour in the safety of new dwellings.

Letters inviting participation were delivered to completed properties on new build developments in the areas of Leicestershire and Nottinghamshire. Two press releases detailing the study objectives were also issued inviting interest.

Semi-structured interviews were conducted within participants homes to collect information on the personal experiences of individuals inhabiting a new dwelling. Home audits were also undertaken with the researcher accompanying occupiers around their properties to identify where problems existed with design features and where modifications had been made. Each interview lasted approximately one and a half hours. The interviews were recorded with the consent of the interviewees and later fully transcribed.

Qualitative data analysis followed three steps: data reduction, data display, verification and conclusion drawing (Miles and Huberman, 1994). Data reduction was achieved by coding the interview data using the qualitative software package Nvivo and pattern coding these units of analysis into a smaller number of themes and explanations. 


\section{In Contemporary Ergonomics 2006 (edited by Philip D. Bust) Taylor \& Francis; London}

\section{Results}

The participant in this case study was a 57 year old male who was dependent on a wheelchair for mobility. He had purchased a two bedroom, ground floor apartment where he lived with his ambulant wife and 32 year old son. At the time of the study, the family had been resident in this property for 9 months.

The study identified a number of problems connected to the physical design and layout of the property, affecting the participants mobility and functioning within the dwelling. Some of these design features relate to the provisions contained in Schedule 1 of the Building Regulations, whilst others were not the subject of any legislation.

\section{Attitude of house builder}

The property was purchased by the occupier 'off plan' (prior to construction), and there were a number of changes that the occupier requested of the house builder during construction to assist him with his disability. These changes included alterations in the bathroom in order that a fully accessible bathroom could be fitted. It appeared that the house building company were reluctant to make any changes or deviate from the standard plan, even though the request was made very early on in the process:-

'We asked for changes to be made, they weren't interested. They knew they could sell them[the homes] ten times over'

Despite such reluctance, the occupier did push the company to make a change to the bathroom:-

'They agreed to that, we had a lot of arm twisting to do it, they didn't want to obviously. Why go to any hassle if somebody's prepared to pay the price as it stands'

\section{Fire Doors}

The main entrance door to the accommodation block where the apartment was located was fitted with a self-closing fire door in line with the provisions contained in Part B of the Building Regulations. This fire door caused problems for the participant in gaining entry to the block:-

'you cannot get into this building in a manual wheelchair, I think you would struggle to get out, there is quite a strong swing on it' [the door]

A self-closing fire door was also fitted to the front door of the property preventing the occupier from gaining easy access to his own property:-

'There was a self-closer, I had to take it off, have you tried opening it with a wheelchair? I wouldn't be able to get in to start the fire'

Self-closing fire doors were also fitted to all habitable rooms within the dwelling itself and once again they caused problems for the occupier:-

'No, there's no way I could open the doors in a wheelchair, it's just not possible, so I've had to take them off'

\section{No ramped exit}

Part $\mathrm{M}$ of the Building Regulations require all dwellings to be accessible for wheelchair users. The entrance to the accommodation described in this study was compliant with these provisions, in that there were no steps to negotiate, but the occupier was concerned regarding his safe exit from the property to his garden:-

'That doesn't have to be suitable for myself, as long as I can get in that's all right'

The difficulties he had experienced in exiting to the garden had resulted in the occupier building a DIY ramp to assist him with his exit:- 


\section{In Contemporary Ergonomics 2006 (edited by Philip D. Bust) Taylor \& Francis; London}

'I've had real problems, I built that ramp out there, I've got another ramp outside as well, but if you saw me going out, you'd have a fit. I didn't like that!'

Due to the rear exit of the property having a raised door threshold, the self built ramp was necessary for the occupier to gain entry to his garden. However, when negotiating the ramp, the participant's wheelchair tipped, leaving him at risk of falling forwards from his wheelchair. (Figure 1)

\section{Figure 1}

\section{Unassisted exit from property in wheelchair}

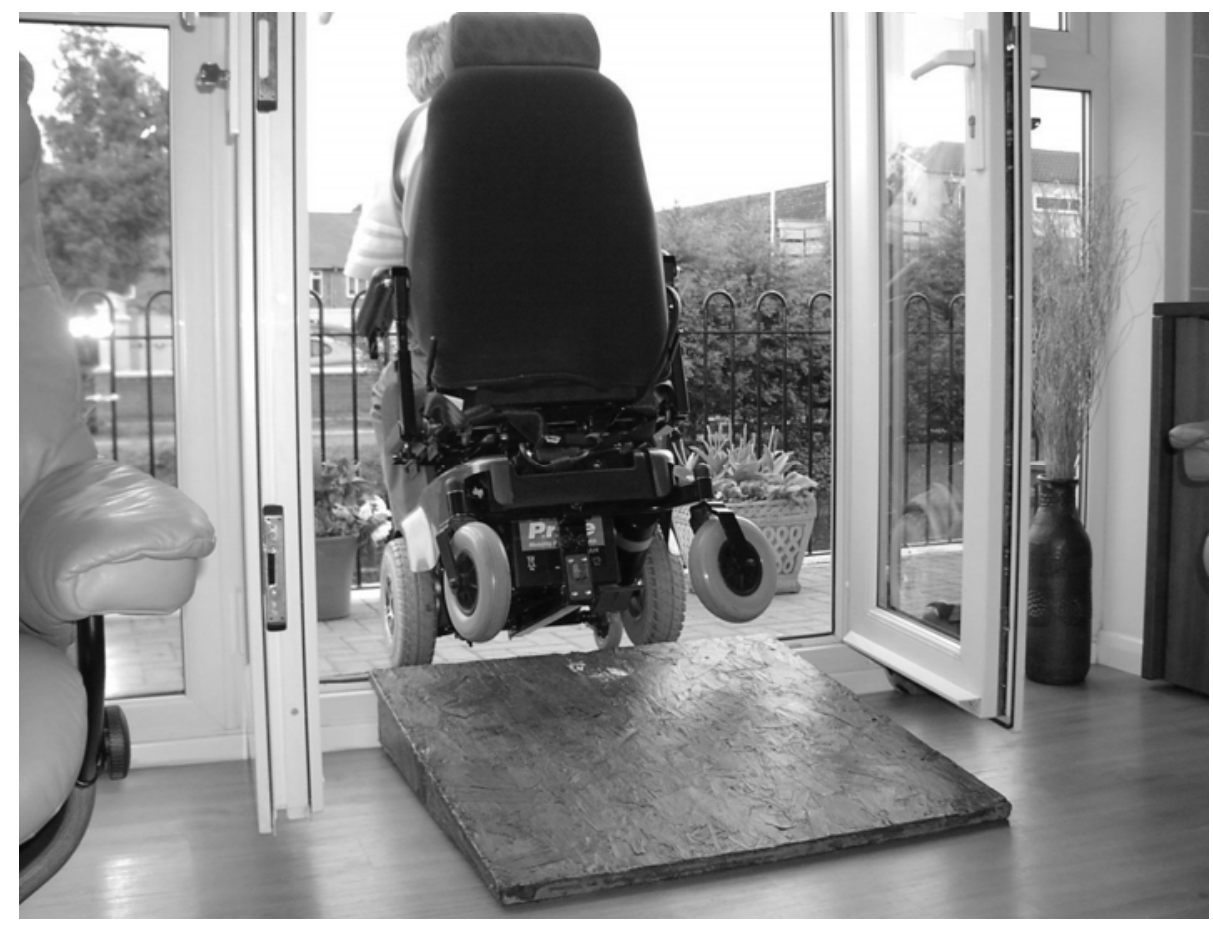

\section{Features}

There were a number of other features of the property that affected the occupier's functioning. These included the fuse box and the spy hole in the front door being at an inaccessible height and the fitted fire blanket being out of reach for a disabled occupier. The communal letter boxes were positioned in the hallway of the block, with the occupier's own box also out of his reach. He also became aware that the disabled parking space provided for the block had been allocated to a first floor apartment, to a fully ambulant occupier.

\section{Discussion}

The examples from this case study demonstrate how some dwellings in Britain continue to be designed with little or no consideration for disabled occupiers. The findings also suggest that the policies of at least one house building company remain rooted in an individual model of disability. 


\section{In Contemporary Ergonomics 2006 (edited by Philip D. Bust) Taylor \& Francis; London}

Many of the problems encountered by the participant in this case study (fuse box, spy-hole etc) could have been avoided through modifications during design and construction. The apparent reluctance of the house builder to make changes during the building of this dwelling, suggests a lack of understanding of the varying needs of disabled people within the house building industry. This supports the claim made by Imrie (2004).

The findings are also in line with previous claims that the provisions within Part $\mathrm{M}$ of the Building Regulations do not go far enough to incorporate the needs of the disabled, (Ridout, 1997). Part M requires electrical sockets and switches within new dwellings to be accessible for a wheelchair user, but these regulations do not cover other internal features within the home.

With regard to injuries in the home, Heywood (2004) identified unadapted or badly adapted housing as one source of these. Examples from this case study that illustrate how this might arise include the need for a self-built ramp and the removal of the fire door closers. This participant's independent exit from the property led to an increased risk of injury to himself and the removal of the self-closers from the internal fire doors created health and safety risks for his family.

The amendments to the Building Regulations (Part $\mathrm{M}$ ), aimed to ensure new dwellings within Britain were, at a minimum, accessible. Part B of the Building Regulations provide the requirements for fire doors in dwellings of a particular design. This study has suggested how the requirements of Part B can inhibit the aims of Part M. The ability of wheelchair users to negotiate fire doors is perhaps an important issue that has received insufficient consideration. A systems approach to the development of Building Regulations is desirable.

Although this case study documents the experiences of only one disabled man, it has highlighted some important issues. The prevalence of these issues in wider society is worthy of future investigation.

\section{References}

Barnes, C. 1991 Disability and Discrimination in Britain.(Hurst and Co, London), cited in Imrie, R. 1998 Focusing on Disability and Access in the Built Environment. Disability and Society, Vol. 13, No 3, 1998

Department of Health 2003 Health Survey for England 2001, (TSO, London).

Heywood, F. 2004 The health outcomes of housing adaptations. Disability \& Society, Vol. 19,No. 2. March 2004.

Imrie, R. 1998 Focusing on Disability and Access in the Built Environment. Disability and Society, Vol. 13, No 3, 1998.

Madigan, R. and Milner, J. 1999 Access for all: housing design and the Disability Discrimination Act 1995. Critical Social Policy, 19 : (3) 396 - 409.

Miles, M.B. and Huberman, A.M. 1994 Qualitative Data Analysis, An expanded sourcebook. (Sage publications)

Ridout, G. 1997 Access Bill. Building Homes. No. 10, pp 28-9. Dec 1997.

Stewart, J., Harris, J. and Sapey, B. 1999 Disability and Dependency: origins and futures of 'special needs' housing for disabled people. Disability \& Society, Vol. 14, No. 1. 